\title{
Prenova poslovanja, nastajanje e-uprave in trenutno stanje $v$ Republiki Slovenji
}

\author{
UDK: $35: 004.9: 659.2$ \\ Marko Colnar \\ Ministrstvo za šolstvo in šport \\ marko.colnar@gov.si
}

\section{IZVLEČEK}

Od začetka snovanja naše e-uprave je minilo sedem let. Obdobje, ki je preteklo, današnji rezultati in primerjave $z$ drugimi državami, so nedvomno primerni mejniki, na katerih se lahko kritično ozremo na projekt, ki je na začetku obetal veliko. Prepričan sem, da obstaja kar nekaj kompetentnih strokovnjakov in ostale zainteresiane javnosti, ki bi jih lahko ta prispevek spodbudil k razmišljanju. Prispevek je zasnovan tako, da je najprej opredeljeno problemsko področje (prenova poslovanja slovenske uprave in e-uprava), sledi opredelitev in uporaba metode dela na opredeljenem problemskem področju (primerjalna analiza, na eni strani, med teoretičnimi izhodišči in dobro prakso pri prenovi poslovanja ter informacijskih sistemih v svetu, in na drugi strani, med potekom prenove, nastajanjem in stanjem naše uprave ter e-uprave). Za spodbuditev nadaljnega razmišljanja pa sta dodani še dve mednarodni študiji o stanju e-uprav v EU in svetu, ki pa diametralno nasprotno slikata stanje slovenske e-uprave.

Namen prispevka je dejansko izpostaviti vprašanje ali je slovenska e-Uprava res zgodba o uspehu, kot to prikazujejo dosedaj vpleteni in odgovorni, ali pa temu ni tako?

Ključne besede: uprava, e-uprava, informatizacija, reorganizacija, prenova poslovanja, stranke

\section{Opredelitev problemskega področja}

Še vedno je prisoten vtis, da je slovenska uprava prevelika, predraga, počasna, neučinkovita, neprijazna... Z njo niso zadovoljni mnogi občani in tudi številni zaposleni. Ker danes živimo $v$ informacijski družbi in je uprava eden ob bistvenih družbenih sektorjev, je smiselno in koristno, da elektronsko poslovanje izkoristimo za podporo optimalnejšemu delovanju uprave. Če k temu dodamo še velike priložnosti in možnosti, ki jih prinaša smiselna in učinkovita vpeljava organizacije in menedžmenta, potem danes težko sprejmemo sporočilo ministra za javno upravo, da je podaljševanje delovnega časa upravnih organov prispevek k prijazni upravi, ali pa da so dodatne pravne redakcije zakonskih in podzakonskih aktov 
Marko Colnar

Prenova poslovanja, nastajanje

e-uprave in trenutno stanje v Republiki Slovenji

velik prispevek k odpravi administrativnih ovir. Cilj sodobne uprave mora biti optimalno notranje delovanje in učinkovito poslovanje s strankami v zadovoljstvo zaposlenim in strankam; to lahko $v$ veliki meri omogoči prav elektronsko poslovanje, vendar ob upoštevanju določenih izhodišč, dejstev in predpostavk, .

\section{O vsebini prispevka in metodi dela}

Prispevek je zasnovan takole: začel bom z izhodišči (kako se lotiti naloge in kakšen naj bo rezultat), sledi oris poteka nastajanja in stanja slovenske e-uprave (kako so se tega lotili odgovorni dosedaj in kaj smo dobili). Medsebojna primerjava (izhodišč in stanja slovenske e-Uprave, z dodanimi mednarodnimi primerjalnimi podatki), kot osrednja metoda dela $v$ tem prispevku, pa naj pokaže, ali je bilo nastajanje slovenske e-uprave res zgodba o uspehu, ali pa stanje ni tako idealno, kot ga prikazujejo odgovorni s tega področja. Ob koncu podajam svoje zaključne ugotovitve, ki vključujejo še kratek predlog scenarija rešitve in sklepno misel. Poenostavljeno gledano je metoda dela primerjalna analiza med ciljnimi (želenimi) lastnostmi dobre e-uprave in konkretnimi lastnostmi slovenske e-uprave. Na tej osnovi temeljijo moje zaključne ugotovitve in sklepna misel, ki jih dodatno ilustrirajo nekatere mednarodne primejave. Metoda prikaza razultatov $\vee$ prispevku je opisna, dopolnjena z nekaterimi podatki, ki služijo kot referenčne točke za prikaz stopnje razvoja in / ali za primerjavo z drugimi (državami) na področju e-uprave.

\section{Izhodišča}

\subsection{Naša dosedanja praksa pri prenovi poslovanja in e-upravi}

Pri prenovi poslovanja slovenske uprave, s katero bi dobili ustrezno osnovo za izdelavo, povezovanje in nadgradnjo informacijskih rešitev (ali estoritev), $v$ zadnjih desetih letih pri pristojnih ni bilo ustrezne podpore, da bi izvedli predvsem najprej posnetek stanja (npr. postopkov, podatkov, organizacije, ...), s katerim bi dobili "sliko naše uprave", na podlagi katere bi videli, kaj, kje in zakaj razvijati informacijske rešitve, marveč je ozka skupina, ki je bila odgovorna (in je še vedno) za razvoj e-uprave, odločala, kaj se bo razvijalo ( $v$ imenu strank in zaposlenih). 
Večkrat jim je bilo predlagano, naj vendarle najprej posnamejo obstoječe stanje, nato povprašajo stranke in zaposlene, kaj potrebujejo, kje so t.i. »ozka grla» in naj na takšni osnovi določijo prioritete sprememb $\vee$ organizaciji posameznih upravnih organov, znotraj teh prioritet pa optimizirajo najprej "ročno poslovanje» in šele nato razvijajo informacijske rešitve, predvsem t.i. "e-storitve", ki strankam in zaposlenim v upravi najbolj koristijo. Namesto tega je prevladovala suverenost razvijalcev, razvijanje informacijskih rešitev, ki so jih čez čas opustili in vztrajanje na nekako treh programskih rešitvah $v$ neštetih variacijah. Prenovo poslovanja pa je, namesto menedžmenta in organizacije, nadomestilo pravno svetovanje (predvsem od zunanjih izvajalcev).

\subsection{Kaj pravi teorija o pristopih k prenovi poslovanja}

Več kot 150 let se vodilni in zaposleni po vsem svetu ukvarjajo z izboljševanji lastnosti organizacij. Največja potreba po njihovem izboljšanju pa se je pojavila, ko so nove tehnologije (računalniki, komunikacije) odprli svetovno tržišče.

Mnogo organizacij, tako vladnih kot privatnih, je vzpostavilo npr. kar poslovne standarde upravljanja kakovosti iz družine ISO 9000. V svetu so se dosedaj uvaljavili nekako štirje pristopi k prenovi (poslovnih) procesov in sicer:

1. FAST (Fast Analysis Solution Technique) - je prodoren pristop, $v$ katerem projektna skupina analizira posamezen proces $v$ nekaj dneh, $s$ ciljem, kako ga izboljšati v treh mesecih.

2. Benchmarking procesa - je sistematičen način za identifikacijo, razumevanje in kreativno uporabo ustreznih produktov, storitev, opreme, s ciljem izboljšanja organizacijskih lastnosti, ko se primerja, kako druge organizacije izvajajo enak proces kot preučevana.

3. Redesign procesa - pomeni izboljšavo sicer dobro delujočega procesa s ciljem, da se zmanjša stroške, čas izvajanja ali napake. Pri tem procesu projektna skupina ne razvije nove informacijske podpore procesu, temveč izkoristi možnosti dobrih praks (drugod).

4. Reinženiring procesa - je najbolj korenit pristop izmed naštetih štirih. Največkrat se ga imenuje "Big Picture Analysis" ali "New Process Design«. Ponavadi se z uporabo tega pristopa razvije nov proces, ki je čimbolj podoben idealnemu.

Pri vseh teh pristopih naj bi prešla organizacija naslednjih šest faz:

1. Organizacija - organiziranje procesa izboljšanja poslovanja 
Marko Colnar

Prenova poslovanja, nastajanje

e-uprave in trenutno stanje v Republiki Slovenji

2. Dokumentacija - izbira metode dokumentiranja procesa

3. Analiza - opredelitev priložnosti, ki jih prinaša izboljšanje poslovanja

4. Zasnova - oblikovanje novih (prenovljenih) administrativnih poslovnih procesov

5. Uvedba - inštaliranje ciljne rešitve

6. Menedžment - upravljanje prenovljene organizacije in procesa stalnega izboljševanja

(Harrington H. James in drugi: Business Process Improvement, 1997).

Pri tem se uporabljajo različne tehnike prikazov rezultatov procesa prenove poslovanja kot: sheme, hierarhični diagrami, matrike, drugi obrazci.

Naj zaključimo: $v$ sodobni informacijski družbi postajajo (poslovni) procesi bolj odvisni od informacijskih sistemov, ki jih podpirajo, kot pa od ljudi, ki jih izvajajo! Prenova poslovanja oziroma (kasnejše) stalne izboljšave so potrebne, če naj organizacija dosega svoje cilje oziroma deluje $v$ sodobnem okolju.

\subsection{Lastnosti dobre e-uprave}

Ves dosedanji razvoj na področju informatizacije $\vee$ naši upravi bi moral (podobno kot $v$ razvitih organizacijah in državah, $s$ katerimi se tako radi primerjamo) potekati $v$ smeri optimiziranja (ročnega) delovanja uprave, vzpostavitve informacijskih rešitev, najprej za t.i. skupne funkcije, $v$ smeri njihovega učinkovitega povezovanja, prek interneta pa na ustrezen način odpiranja tudi strankam, vse to pa še nadgrajeno s sistemi za potrebe upravljanja in odločanja.

Predlagam, da naj bi e-uprava imela naslednje štiri lastnosti:

1. e-uprava bi morala biti "slika" (ogledalo) optimalne organizacije in delovanja upravnih organov; večkrat govorimo prav o e-upravi kot vzvodu za prenovo poslovanja slovenske uprave,

2. e-uprava bi morala vsebovati predvsem in najprej tiste storitve, ki jih stranke (najbolj) potrebujejo,

3. informacijske rešitve e-uprave bi morale pomeniti razbremenitev dela zaposlenih $v$ upravnih organih in ne nalaganje dodatnega dela,

4. vse informacijske rešitve e-uprave bi morale biti enostavne, struktura (ponudba) portala e-uprava pa konsistentna, jasna in pregledna. 


\subsection{Kako se v svetu lotevajo razvoja spletnih informacijskih sistemov}

Informacjski sistemi (IS) so že mnogo let bistveni pogoj za preživetje organizacij, v zadnjem času pa se izpostavlja nekako štiri dejavnike, ki še dodatno poudarjajo njihov pomen:

1. Globalna ekonomija - sodobne uspešne organizacije morajo biti sposobne delovati globalno, tekmovati na celotnem svetovnem trgu, upravljati dobavitelje, stranke in to 24 ur na dan, vse dni v letu.

2. Industrijska transformacija - današnje organizacije temeljijo na znanju in storitvah. Mnogo dejavnosti temelji na kreiranju in distribuiranju informacij. Posledično, proizvajalci potrebujejo manj strojnikov in več oblikovalcev, razvijalcev in IT specialistov.

3. Poslovna transformacija - tradicionalno poslovanje je (bilo) organizirano hierarhično in temelječe na operativnih postopkih, ki dobavljajo storitve in proizvode. Novi pristopi k poslovanju pa imajo vire organizirane okrog proizvoda ali storitve oziroma stranke.

4. Digitalna podjetja - e-poslovanje upravlja odnose strank, dobaviteljev in zaposlenih in je sposobno reagirati na spremembe iz okolja bliskovito.

Glede na to so torej potrebni ustrezni pristopi pri razvoju sodobnih, internetnih IS. Mnogo od njih je usmerjenih v uporabniški vmesnik, ne pokrivajo pa ustrezno vseh potrebnih zalednih IS. Zato so potrebni "večdimenzionalni« pristopi, ki so prikazani na sliki 1.

Slika 1: Matrika elementov razvoja IS po metodi WISDM (Web IS Development Methodology)

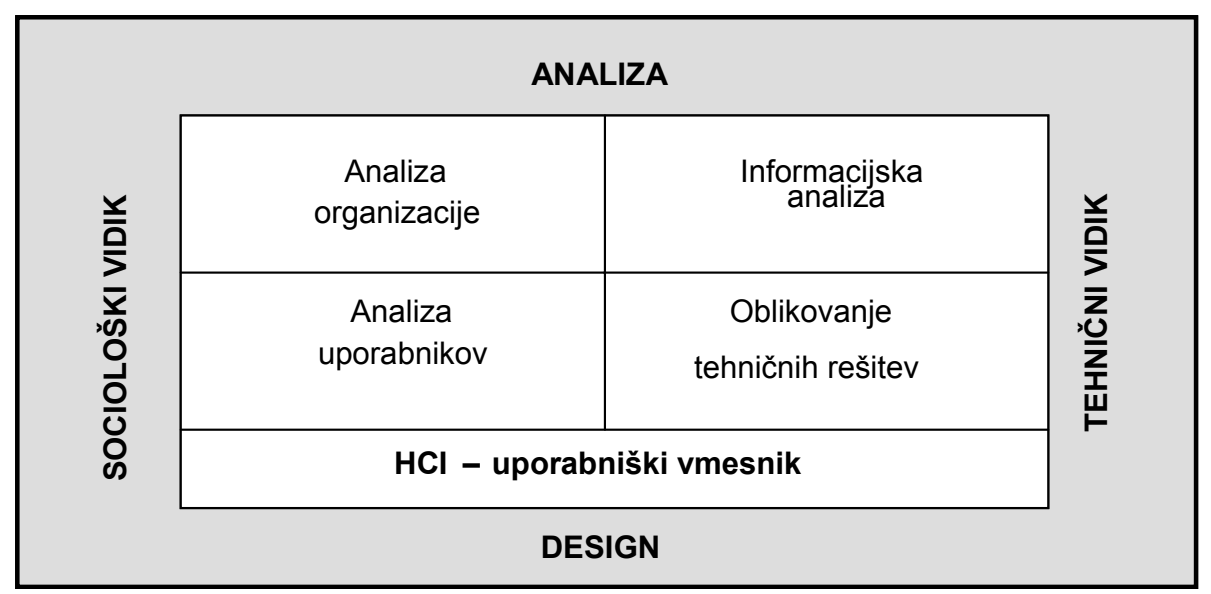

Vir: Vidgen Richard in drugi: Developing Web Information Systems, 2004. 
Marko Colnar

Prenova poslovanja, nastajanje

e-uprave in trenutno stanje v Republiki Slovenji

\section{Potek prenove poslovanja in nastajanje e-uprave pri nas}

Reforma slovenske uprave se danes, po moji oceni, (še vedno) nahaja nekje $\vee$ prvi polovici procesa; čaka nas še mnogo neprehojene poti. Ne predstavljamo si drugačnega pristopa, kot da začnemo s posnetkom in prenovo procesov (nekateri to imenujejo tudi prenovo poslovanja), ki naj vodi $v$ učinkovitejše oblike organizacije upravnih organov. Šele nato postavljajmo ustrezne informacijske rešitve (sisteme). Če omenimo elektronsko poslovanje oziroma e-upravo, kot enega glavnih uporabnikov rezultatov prenove poslovanja, potem je nujnost kvalitetnejše in hitrejše prenove poslovanja še toliko večja (da ne bomo gradili e-uprave na starih procesih in organizacijah).

$\checkmark$ svetu velja (predvsem za velike organizacijske sisteme), da se s prenovo poslovanja in informatizacijo lahko prihrani od $20 \%$ do $40 \%$ stroškov, samo z informatizacijo, brez prenove poslovanja pa ne. In zakaj je to za nas tako pomembno? Predvsem zato, ker dosedanji potek prenove slovenske uprave ni potekal $v$ tem smislu. Ob predstavljanju posameznih informacijskih rešitev $s$ področja e-uprave, odgovorni sicer populistično praviloma vedno navajajo tudi velike prihranke, vendar pa virov podatkov in algoritmov za izračun teh prihrankov skoraj nihče ne uspe odkriti.

\subsection{Dosedanji potek prenove poslovanja slovenske uprave}

Stanje na področju prenove procesov slovenske uprave najbolje prikazujejo nekatere pretekle aktivnosti (projekti, inštitucije), ki so nanizane kar kronološko. Opisane so z različno podrobnostjo, ker so se bodisi končale na različnih stopnjah finalizacije, ali pa še potekajo.

Projekt "Reforma slovenske javne uprave"

V letih 1996 in 1997 se je začel projekt preobrazbe slovenske javne uprave $\checkmark$ luči približevanja EU, katerega nosilec je bilo ministrstvo za notranje zadeve. Projekt je po dobrem letu dni zvodenel oziroma ni bilo konkretnejših informacij o morebitnih rezultatih.

Projekt "Prenova poslovanja in informatizacija upravnih enot RS« (IUE) oziroma kasneje imenovan (PPUE)

Projekt se je začel leta 1997. Tekom izvajanja projekta je stalno prihajalo do novih zahtev in nepotrebnih zapletov, dokončno pa se je zataknilo pri verifi- 
kaciji izdelkov 1.faze (t.j. posnetih 58 upravnih postopkov), čeprav se je vedelo, kdo je bil za to pristojen.

Proti koncu leta 2001 se je projekt zagnal še tretjič, tokrat poimenovan „PPUE name in verificira vsaj splošni upravni postopek. To se je poleti leta 2002 res zgodilo, vendar pa se potem ni vedelo, kaj bi z njim.

Projekt "Kakovost v državni upravi « Odbora za kakovost Ministrstva za notranje zadeve - Urada za organizacijo in razvoj uprave

Vlada RS je jeseni leta 1996 z namenom, da bi dosegla približevanje evropskim standardom in izpolnjevanje zahtev standarda ISO-9001, sprejela politiko kakovosti državne uprave.

Ministrstva in vladne službe so se tega projekta lotile same, za upravne enote Republike Slovenije pa je koordinacijo prevzelo Ministrstvo za notranje zadeve - Odbor za kakovost, ki je deloval v okviru Urada za organizacijo in razvoj uprave.

Postavlja se vprašanje: zakaj je vsaka posamezna upravna enota, izvajala projekt sama, če je bil zato ustanovljen Odbor za kakovost, ki bi lahko vzpostavil ustrezno »metodologijo pridobivanja certifikatov« za vse upravne enote?

Ustanovitev Komisije Vlade Republike Slovenije za odpravo administrativnih ovir

Vlada je spomladi leta 2001 ustanovila in imenovala to komisijo, ki je pripravila ustrezna izhodišča, se sestajala in delovala dokaj redno, njeni rezultati so bili še najbolj vidni na področju podjetništva, upravnih enot, okolja in prostora, notranjih zadev, povezav državne uprave z drugimi organi javne uprave (ZPIZ, CSD, ...).

Lahko pa ugotovim, da je komisiji manjkal konkreten mehanizem merjenja, poročanja in ukrepanja. Z letom 2003 je bila komisija ukinjena.

Vprašalniki (metodologija) Ministrstva za notranje zadeve - Urada za organizacijo in razvoj uprave

Jeseni leta 2001 je Urad za organizacijo in razvoj pripravil tkim. "Metodologijo«, ki jo je sestavljalo pet vprašalnikov.

Vprašalniki so bili zelo obsežni, ob njih pa se je odpiralo več vprašanj.

Glede na to, da po zaključeni akciji ni bilo nobenih informacij in glede na dejstvo, da je ta organ spomladi leta 2002 to akcijo ponovil, z nekoliko modificiranimi vprašalniki, vendar $v$ svojem bistvu še vedno enakimi in obsežnimi, gre 


\section{Marko Colnar \\ Prenova poslovanja, nastajanje \\ e-uprave in trenutno stanje v Republiki Slovenji}

sklepati, da so bila porajana vprašanja v prvem krogu smiselna. Ugotavljam še, da tudi po drugem krogu ni bilo konkretnejše predstavitve rezultatov.

\subsection{Nastajanje slovenske e-uprave}

$\checkmark$ dosedanjem razvoju naše e-uprave ugotovljam, da so vseskozi manjkali koncept, objektivna analiza potreb strank in zaposlenih ter jasne pristojnosti posameznih resorjev, kljub temu, da je bil pomemben del akcijskega načrta AN2004 seznam projektov za e-storitve po resorjih.

Posledica takega stanja je, na eni strani portal E-uprava, pod okriljem (sedaj) ministrstva za javno upravo, na drugi strani pa obstoj še nekaterih pomembnih portalov s področja elektronskega poslovanja upravnih organov, ki so po pomembnosti vsaj na enakem nivoju kot portal E-uprava in sicer, npr.: Edavki, E.zemljiška knjiga, E-kataster, itd.... Če k temu dodam še, da ministrstvo za javno upravo vodi in izvaja npr. projekta "e-VEM «, ki je gospodarski projekt in "Podaljšanje prometnega dovoljenja», ki je projekt ministrstva za notranje zadeve, potem je zmeda tukaj. Namreč, ne ve se, kaj je sedaj vstopni portal Euprava, mešajo se pristojnosti med resorji za vodenje konkretnih projektov, $v$ medijih predstavniki enega ministrstva predstavljajo projekte drugega, ocenjujejo prihranke za njihove stranke, predstavljajo načrte za prihodnost, ki so pisani na kožo njihovim interesom, še zlasti zaradi populističnega nabiranja političnih točk. In kaj potem lahko pričakujejo od takega sistema e-uprave dejansko stranke in zaposleni? Ali se kaj vpraša tudi njih?

Projekt "e-uprava" se je formalno začel v začetku leta 2001, ko je bila vzpostavljena prva verzija državnega portala. Enotni državni portal naj bi zagotavljal javnosti dostop do vseh informacij in storitev javne uprave (24 ur x 365 dni), na enostaven in prijazen način tako, da uporabniku ne bi bilo treba poznati notranje organizacije in postopkov javne uprave. Bil naj bi skupna enovita predstavitev državnih organov Republike Slovenije na internetu. Tako bi se javna uprava približala državljanom Slovenije, ter bila naj bi bolj prijazna, uporabna .... To so bili načrti leta 2001.

Leta 2002 je bila sprejeta "Strategija uvajanja elektronskega poslovanja v državni upravi za obdobje od leta 2001 do leta 2004« (SEP-2004). Z njo je bila vzpostavljena strateška podlaga za uvajanje elektronskega poslovanja $v$ državno in javno upravo RS. Kljub jasnim usmeritvam in ciljem, izvajanje strategije ni bilo zadovoljivo in učinkovito, čeprav je bil dosežen velik napredek predvsem na področju tehnološke infrastrukture in ključne zakonodaje. Državni organi bi 


\section{Marko Colnar \\ Prenova poslovanja, nastajanje e-uprave in trenutno stanje v Republiki Slovenji}

morali prevzeti večjo pobudo in nosilno vlogo pri uresničevanja posameznih projektov elektronskega poslovanja na njihovih področjih, v skladu z njihovimi pristojnostmi, ob zagotavljanju učinkovite skupne organizacijske in tehnološke podpore.

Po sprejetju SEP-2004 so bili vsekakor storjeni pozitivni premiki na področju informatizacije in dostopa do interneta $v$ RS. Kljub nekonsistentnosti podatkov (virov), so primerjave razvitosti na tem področju, zlasti z državami kandidatkami za članstvo v EU, vseeno kazale dokaj ugodno podobo.

Predvsem se je povečalo število uporabnikov interneta $v$ RS, pojavili so se novi ponudniki internetnih storitev (kabelski operaterji, operaterji mobilnih telekomunikacijskih storitev) in povečalo se je število uporabnikov sodobnih tehnologij in storitev (ISDN, ADSL,...). S tem se je povečala baza potencialnih uporabnikov e-storitev javne uprave.

Vzpostavitev dobre e-uprave zahteva v vseh državah veliko napora (nove estoritve, vzpostavitev učinkovitih mehanizmov za izvajanje in spremljanje projektov vzpostavljanja e-uprave, učinkovito promocijo ter uvajanje uporabnikov in še mnogo drugih pogojev, ki morajo biti izpolnjeni). Zato je tudi Republika Slovenija, po sprejetju Strategije SEP-2004, sprejela še njen izvedbeni dokument "Akcijski načrt e-uprave do leta 2004" (AN-2004).

Nabor e-storitev, aplikacij in nalog $v$ njem je nastal na podlagi usklajevanj znotraj delovne skupine, usklajevanj z organi uprave, primerjav z drugimi državami, ki so uvajale e-upravo, še zlasti s članicami EU in takrat še pridruženimi članicami. Nabor e-storitev se je tekom izvajanja projektov oziroma realizacije akcijskega načrta tudi dopolnjeval.

Redno se je preverjalo uvajanje e-storitev in stopnja uvedbe. $V$ ta namen je bilo potrebno vzpostaviti učinkovite mehanizme za izvajanje in spremljanje projektov ter redno skrbništvo akcijskega načrta.

Ustanovljena je bila "projektna pisarna " na takratnem Centru Vlade RS za informatiko in zagotovljena informacijska podpora $\vee$ obliki intranetne aplikacije »Programsko projektna pisarna«.

Za spremljanje izvajanja akcijskega načrta je bila uporabljena evropska merska lestvica "eGovernment indicators for benchmarking eEurope", ki je bila že uveljavljena pri spremljanju akcijskih načrtov eEurope in eEurope+. Uporabljale so se stopnje od 0 do 4 za vrednosti kazalnika - indeksa e-uprave. 
Marko Colnar

Prenova poslovanja, nastajanje

e-uprave in trenutno stanje v Republiki Slovenji

$\checkmark$ akcijskem načrtu se je za vsako e-storitev, ki je bila uvrščena pod določeno podpodročje, ocenjevala trenutna stopnja e-poslovanja in ciljna stopnja e-poslovanja ter rok v katerem se želi doseči ciljno stopnjo e-poslovanja.

Ob vsakem razdobju osveževanja akcijskega načrta sta se ugotavljala trenutna stopnja in približevanje ciljni stopnji.

Mesečno so se sestajali vsi pristojni posameznih upravnih resorjev oziroma vodje projektov in poročali o stanju svojih projektov za e-storitve slovenske e-uprave. Vlada RS pa je dvomesečno obravnavala zbirna poročila (povzeto po Center Vlade RS za informatiko, Akcijski načrt e-Uprave do leta 2004 (AN2004), 2003).

Po izteku Strategije SEP-2004 in Akcijskega načrta AN-2004, kjer je bil vzpostavljen portal e-uprave in program projektov za elektronske storitve euprave, se je vendarle vseskozi, kljub precejšnjim pozitivnim premikom in rezultatom, ugotavljalo, da naša e-uprava le nima nekega jasnega koncepta, da se ne razvija vedno tistih storitev, ki so dejansko najpotrebnejše, da obstajajo problemi stopnje uporabe že izdelanih in objavljenih e-storitev na portalu euprave.

$\checkmark$ ta namen je bil $\vee$ drugi polovici leta 2004 vzpostavljen še projekt »merjenja zadovoljstva strank e-uprave«, ki naj bi objektivno in konkretno zagotovil razvijalcem "povratne informacije» e-uprave, o tem, kaj si stranke dejansko želijo in opozoril na nekatere probleme, pasti ter ponudil tudi (mednarodne) primerjave. Rezultati tega projekta uradno niso bili objavljeni.

V letu 2005 se na področju slovenske e-uprave ni zgodilo praktično nič, z izjemo vzpostavitve medresorske skupine "za boljšo koordinacijo e-uprave«, ki je poskušala "oponašati predhodno skupino", katere delovanje se je ustavilo nekje novembra 2004. Vendar pa sodelovanje (samo za ilustracijo - od zadnjega sestanka te skupine je minilo že več mesecev) poteka $v$ nekem mlačnem vzdušju, nekih omembe vrednih rezultatov pa ni.

\section{Dejanski dosežki slovenske e-uprave}

Na podlagi orisa poteka prenove poslovanja in nastajanja slovenske euprave iz predhodnega poglavja lahko ugotovimo:

Nabor "e-storitev", postavljen v dokumentu SEP-2004 in predvsem v AN2004, je bil precej celovit in večkrat medresorsko usklajen. Končna stopnja 


\section{Marko Colnar \\ Prenova poslovanja, nastajanje e-uprave in trenutno stanje v Republiki Slovenji}

realizacije e-storitev, ob zaključku mandata AN-2004, pa je bila cca 35\%. Postavlja se vprašanje: kaj je (bilo) s preostalimi $65 \%$.

Kljub začetnemu zagonu, da bi ponudili rešitve, ki bi strankam in upravnim organom pomenile razbremenitev in konkretne koristi (resnično dodano vrednost), se je zadeva počasi začela razvijati $v$ smer, ki jo je narekoval relativno zaprt krog odločevalcev.

Cilje, storitve in podatke oziroma koncept e-uprave bi bilo treba "preslikati« $v$ (re)organizacijo in boljše delovanje (optimirane postopke) upravnih organov. S tem bi dobili okvire, po katerih bi se lotili celovite prenove poslovanja (ne samo pisanja/popravljanja zakonodaje). Poleg tega bi morali prisluhniti tudi strankam in samim zaposlenim $v$ upravnih organih (kaj dejansko $v$ življenju potrebujejo, kaj so ozka grla pri delu, ...). Tako bi dobili merila in kriterije, po katerih bi določevali prioritete za razvoj določenih storitev sistema e-uprave.

Toda so se projekti razvijali brez omenjenih okvirov, kot da je pri razvoju slovenske e-uprave prevladoval kriterij kvantitete in ne kvalitete.

Portal e-uprave se je polnil s "čimveč vsega", zato je postajal vedno bolj nejasen. Vmes se je sicer prenovil dvakrat, vendar se je opažalo, da cilji prenove niso izhajali iz kakšnega koncepta e-uprave ali pričakovanj in potreb strank. Danes na njem prevladujejo $v$ glavnem informacije in malo pa je estoritev, kajti le-te (npr. stopnje 4 ali 5 po evropski metodologiji) bi zahtevale predhodno prenovo poslovanja in popolnoma jasne pravne oziroma vsebinske verifikacije, teh pa se ni znalo zagotoviti. Občutek je, da so razvijalci sicer izdelali peščico e-storitev, vendar predvsem tiste, ki jih je bilo sorazmerno enostavno razviti.

$\mathrm{K}$ temu je morda delno pripomogla tudi metodologija EU »eGovernment indicators for benchmarking eEurope«, ki je narekovala 20 življenskih dogodkov (12 za prebivalce in 8 za poslovne subjekte). Navedimo citat iz objavljenega prispevka dnevnika Finance: "Zaradi spremljanja 20 izbranih e-storitev so se vse države - s Slovenijo vred - zaletele $v$ njihovo zagotavljanje. Akcijski načrt tako spremlja samo faze, $v$ katerih projekti so, ne pa tudi njihove dejanske uspešnosti

Vlada RS je leta 2006 sicer sprejela tudi novo strategijo e-uprave z naslovom "Strategija e-uprave v RS za obdobje od leta 2006 do leta 2010" (SEP2010), leta 2007 pa še akcijski načrt AN2007/2010. Ob teh dveh dokumentih, ki naj bi začrtala nov zagon razvoja slovenske e-uprave, naj poskusim navesti konkretne rezultate e-uprave $v$ zadnjih treh letih - tri leta zato, ker je po preteku 
Marko Colnar

Prenova poslovanja, nastajanje

e-uprave in trenutno stanje v Republiki Slovenji

mandata strategije SEP-2004 to novo formalno obdobje slovenske e-uprave, ki pa sovpada tudi z mandatom nove Vlade RS.

Z izjemo storitve "eVEM (enotna vstopna točka za registracijo in poslovanje podjetnika posameznika), neposrečeno izbrane upravne storitve - elektronskega podaljšanja prometnega dovoljenja in ponudbe dvanajstih obrazcev za komuniciranje z občinami, stranke niso dobile praktično nobene nove estoritve (Državni portal E-uprava: http://e-uprava.gov.si/e-uprava/).

\section{Nekaj primerjalnih podatkov o e-upravah}

Za ilustracijo navedimo, v zadnjem času zelo aktualna dva vira mednarodnih podatkov, ki slovensko e-upravo ocenjujeta diametralno nasprotno. Bralci si lahko sami ustvarijo sliko o korektnosti obeh; predvsem tisti, ki so že uporabljali portal e-uprava.

\subsection{Podatki univerze Brown}

V študiji z naslovom "Global E-Government, 2007« je avtor Darrell M. West s sodelavci analiziral 1.687 internetnih strani - e-uprav iz 198 držav.

Metoda primerjalne analize je vsebovala:

- elektronske storitve

- zasebnost in varnost

- dostopnost domačih strani

- tuji jeziki, v katerih so ponujene elektronske storitve

- stroške elektronskih storitev

- e-demokracijo

$\checkmark$ bistvu gre za neko varianto »indeksa e-uprave«. Slovenija je uvrščena na 82. mesto, leta 2006 pa na 45.; prva je Južna Koreja, drugi Singapur, tretji Tajvan (celotna lestvica in obrazložitve so $v$ dokumentu Global E-Government 2007, Brown University, 2007, http://www.insidepolitics.org/egovtdata.html).

\subsection{Podatki evropske komisije}

V študiji z naslovom "The User Challenge Benchmarking The Supply Of Online Public Services, 7th Measurement, September 2007« je analiziranih 27 držav, članic evropske skupnosti in še Islandija, Norveška, Švica in Turčija. 
Metodologija primerjalne analize je $\vee$ bistvu "eGovernment indicators for benchmarking eEurope«, ki vsebuje 20 življenskih dogodkov (12 za prebivalce in 8 za poslovne subjekte). Vsak izmed teh življenskih dogodkov ima svojo ciljno stopnjo (nikakor nimajo vsi dogodki ciljne stopnje 5!), skupni indeks e-uprave, kot dejansko ta kazalnik imenujemo pri nas, pa se meri $\vee$ odstotkih realizacije vseh trenutnih stopenj razvitosti življenskih dogodkov glede na njihove ciljne. Trenutno metoda obsega pet stopenj:

$0 . \quad$ ni informacij

1. pojaviti se (prisotnost uradne vladne on-line strani),

2. stopnjevanje (informacije postanejo bolj dinamične),

3. interaktivno (uporabniki si "snemajo obrazce«, po elektronski pošti poslujejo z uradniki),

4. transakcije (uporabniki lahko plačajo posamezne storitve),

5. integracija (popolna integracija elektronskih storitev po vsej upravi).

Slovenija je uvrščena na 2. mesto, leta 2006 pa je bila na 7. Celotna lestvica in obrazložitve so $v$ dokumentu The User Challenge Benchmarking The Supply Of Online Public Services, 7th Measurement, September 2007, http://ec.europa.eu/ information_society/eeurope/i2010/docs/benchmarking/egov_benchmark_2007.pdf).

\section{Zaključne ugotovitve}

\subsection{Obstaja več vidikov prenove poslovanja slovenske uprave}

Če torej obravnavamo slovensko upravo kot organizacijski sistem, potem je primerno, da pristopimo k prenovi čimbolj sistematično. To nam kasneje zelo olajša delo, kajti že analiza stanja nam, ob striktni uporabi ustrezne metode dela in tehnik prikaza rezultatov, zagotovi modele, ki celovito prikazujejo obstoječe stanje sistema naše uprave, na katerem potem, z isto metodo in tehnikami prikaza rezultatov, izgradimo ciljno stanje (modele). Pristopimo $k$ analizi in prenovi naše uprave najmanj skozi:

1. Institucionalni vidik (zakonodaja),

2. Vsebinski vidik (upravni postopki, drugi procesi in podatki),

3. Organizacijski vidik (notranja organizacija, menedžment),

4. Kadrovski vidik (sistemizacija, menedžment) in

5. Informacijski vidik (e-uprava, baze podatkov, druge aplikacije, povezave).

(Colnar, Kako do prenove slovenske uprave, 2006, str. 73) 
Marko Colnar

Prenova poslovanja, nastajanje

e-uprave in trenutno stanje v Republiki Slovenji

\subsection{Za začetek bi bila potrebna kakovostna strategija e-uprave}

Strategija e-uprave Republike Slovenije za obdobje 2006 do 2010 (SEP2010), ki jo je, na predlog Ministrtstva za javno upravo - Direktorata za e-upravo in upravne procese, sprejela spomladi leta 2006 Vlada RS, je formalno sicer potreben dokument (skupaj z izvedbenim dokumentom Akcijski načrt e-uprave do leta 2010 (AN-2007/2010)), treba pa je opozoriti, da je bilo v procesu nastajanja strategije podanih precej tehtnih pripomb, ki jih avtorji niso upoštevali.

Konkretno naj navedemo nekaj teh:

- $\quad$ sprejeti dokument je, $v$ bistvu predelana verzija dokumenta, ki ga je zapustila delovna skupina koncem leta 2004, potem, ko je potekla veljavnost stari strategiji SEP-2004 oziroma potem, ko je bil ukinjen Center Vlade RS za informatiko,

- nikjer ni omenjeno, kaj bo v letu 2006 storila ekipa projekta e-uprave s preostankom nerealiziranih $65 \%$ e-storitev, ki so ostale ob koncu leta 2004, (po Akcijskem načrtu e-uprave do leta 2004 - AN-2004)

- nova strategija SEP-2010 bi morala izhajati iz realnega (opisa) trenutnega stanja in ne iz večkratnega naštevanja samo nekaterih že izdelanih rešitev, brez kritične analize oziroma dejanskih problemov,

- ob sprejetem dokumentu je ostalo neodgovorjeno vprašanje - kaj se je naredilo na e-upravi v letu 2005, pa tudi še v letu 2006,

- dokument ne ponuja konkretnejših smernic za informacijske rešitve za stranke in zaposlene v slovenski upravi - floskule tipa "Zadovoljni uporabniki so vodilo sodobne e-Uprave .....itd..." verjetno ne dajejo pravega odgovora,

- kakšnem konceptu e-uprave $v$ dokumentu ni sledi, njegovo pomanjkanje $\vee$ dosedanjih več kot sedmih letih pa se še kako pozna,

- in še precej drugih.

\subsection{Digitalni certifikati}

Vsekakor je varnost v elektronskem poslovanju prvi imperativ. Vendar je to vprašanje treba rešiti smiselno, tako z vsebinskega in s tehnološkega vidika. Zahtevanje digitalnih certifikatov $v$ naši e-upravi, pri skoraj vsaki e-storitvi, je vprašljivo (medtem ko nam danes poštarji nosijo domov npr. dohodninske odločbe kar v vrečkah, ki se lahko valjajo tudi na cesti, pri sosedu). Izbrana tehnologija je prezahtevna za povprečnega uporabnika oziroma za te e-storitve 
(sicer dobra, vendar pa je namestitev certifikata večkrat problem tudi za računalničarja).

Po vseh teh letih, se je ekipa e-uprave končno začela ozirati tudi za drugimi, enostavnejšimi, vendar ustreznimi certifikati.

Ponovno pa bo treba premisliti o seznamu e-storitev, ki naj bi jih digitalni certifikat sploh ščitil.

\section{4 Še ena zabloda}

Predstavitev "generičnega življenskega dogodka», ki naj bi ga določeni pristojni zaposleni $\vee$ upravnih organih kar vnašali prek portala e-uprave, od vodje projekta e-uprave, kaže: da se je "snovalec" prelahkotno lotil analize vsebinskega stanja upravnih organov in je zato neprimerno poenostavil informacijsko rešitev, ki temelji na nekaterih napačnih predpostavkah.

Verjetno gre $v$ tem primeru za zahtevnejše aplikacije, ki nujno temeljijo na najprej vsebinsko optimiziranih in povezanih delovanjih upravnih organih.

Ker je od tega bistveno odvisen nadaljnji uspeh (uporaba) e-uprave (čimveč e-storitev stopnje 4 ali celo 5, od katerih imajo vsi največ koristi), bi kazalo na to temo izvesti kakovostno razpravo ustreznejših poznavalcev te tematike!

\subsection{Kaj bi od slovenske e-uprave dejansko lahko dobili}

Najprej bi bila potrebna kakovostna strategija; sprejetemu dokumentu SEP2010 namreč manjka najmanj:

- objektivna analiza stanja,

- realne predpostavke,

- koncept,

- in še marsikaj ...

Nato bi kazalo čimprej izvesti celovito prenovo poslovanja naše uprave osnova za sodobne in učinkovite "e-storitve«, t.i. 4. ali 5.stopnje po evropski merski lestvici in od katerih imajo stranke največ koristi

Nadalje bi morali vzpostaviti učinkovito organizacijo za razvoj informacijskih rešitev e-uprave, spremljanje, poročanje in ukrepanje.

$\mathrm{Pa}$ ne pozabiti na zaposlene in stranke e-prave kot tiste vzroke, zaradi katerih se uprava sploh prenavlja in informatizira (in ne zaradi vodje projekta in zunanjih izvajalcev). 
Marko Colnar

Prenova poslovanja, nastajanje

e-uprave in trenutno stanje v Republiki Slovenji

Glavni (ne edini) rezultat za vse - stranke in zaposlene (uporabnike) euprave - bi bil npr. prijazen portal, ki bi ponujal želene in ustrezne e-storitve upravnih in drugih organov, povezane tako, da bi stranke od doma, zaposleni pa brez njih, rešili glavnino problemov. Zaposlenim $v$ upravnih organih bi odpravil še večino rutinskih in administrativnih del in bi jim tako opustil čas za upravljanje, odločanje in nadaljno prenovo poslovanja.

\subsection{Scenarij prenove poslovanja in nadaljnega razvoja e-uprave pri nas}

1. Uporabimo ustrezen pristop: bistvo reševanja nekega problema ali začetka razvoja nekega sistema (projekta) je $\vee$ pravi izbiri in dosledni uporabi ustrezne metode dela.

Že $\vee$ mnogih projektih naše uprave se je izkazalo, da je, tudi za potrebe prenove procesov oziroma poslovanja, zelo uporabna t.i. »informacijska metoda" (konkretno: EMRIS - enotna metodologija razvoja informacijskih sistemov) oziroma njena prva faza - Strateško planiranje in njen glavni izdelek t.i. "pregledni model" (ki vsebuje organizacijsko strukturo, procese, podatke in povezave med njimi). Žal skoraj vsi dosedanji pristojni in vsebinski udeleženci prenove poslovanja slovenske uprave niso hoteli dopustiti vsaj predstavitve, kaj šele, da bi sprejeli tudi argumente in metodologijo uporabili!

Dejstvo je, da najmanj polovica projektne skupine, npr. informacijskega projekta, sestavljena iz tkim. "vsebinskih ljudi«. Tako ti, ob snovanju t.i. »uporabniških zahtev", sproti ustvarjajo tudi spremembe v procesih in organizaciji, za katero kasneje gradijo ali prenavljajo IS. Nesmiselno je graditi nov IS za slabo in neučinkovito organizacijo in delovanje!

2. Posnetek stanja - „pregledni model« je nujno potreben: ne moremo si zamisliti začetka prenove kakršnegakoli objekta ali sistema, brez celovitega posnetka obstoječega stanja. Predlagana metoda dela in tehnike prikaza rezultatov nam omogočajo, da izdelamo celovit "pregledni model" in vse (pod)modele slovenske uprave, na katerih jasno vidimo delovanje posameznega upravnega organa ali celotne uprave, identificiramo probleme (ozka grla, nekonsistentnosti, redundance, ali pa npr. manjkajoče elemente). Dosedaj $\vee$ naši upravi še ni bilo aktivnosti, ki bi omogočile pripravo celovite slike stanja.

3. Ob izdelavi "preglednega modela obstoječega stanja uprave", postavimo cilje (dobre) organizacije in izvedemo kritično analizo: ko smo naredili 


\section{Marko Colnar \\ Prenova poslovanja, nastajanje e-uprave in trenutno stanje v Republiki Slovenji}

celovit "pregledni model obstoječega stanja uprave", nanj postavimo cilje dobre organizacije, ki veljajo tudi za upravo ter obstoječe stanje kritično analiziramo. S tem smo dobili nastavke za ciljni "pregledni model« prenovljene uprave.

4. Izdelamo tudi "pregledni model prenovljene uprave«: na temelju nastavkov iz predhodne točke projektiramo (lahko rečemo kar konstruiramo, ali razvijemo, ali izdelamo) celoviti "ciljni pregledni model bodoče prenovljene uprave .

5. Veliko lahko naredimo na področju organizacije: kot smo že omenili, so organizacijski, vsebinski in kadrovski vidiki zelo pomembni (vmesni med institucionalnim in informacijskim). Množično izgovarjanje na potrebne zakonske spremembe je neproduktivno in zavajajoče. (Re)organizacija je danes učinkovito orodje za izboljšanje delovanja. Pri tem gre, $v$ našem primeru, $v$ veliki večini za večje ali manjše spremembe $v$ notranji strukturi upravnih organov, $\checkmark$ tesni povezavi s spremembo strukture upravnih in drugih postopkov (ne njihove spremembe). Organizacija je relativno poceni orodje in skrita notranja rezerva v sistemu (vedno je možno še kaj izboljšati, investicije pa niso velike).

6. Kadri in menedžment so temelj sodobne organizacije: $v$ tesni povezavi $s$ sodobno organizacijo je vodenje in upravljanje kadrov, ki pa morajo tudi sami spremeniti miselnost (odnos do strank - kupci upravnih storitev, odnos do virov za njihovo delo = ključ do učinkovitejšega poslovanja). Posebno pozornost je potrebno posvetiti tudi izobraževanju vodij; t.i. upravni menedžment ( "New Public Management «) je ena od osnov profesionalizacije sodobne uprave.

7. Elektronsko poslovanje uprave mora olajšati delo zaposlenim in povečati dostopnost njihovih storitev: dejstvo je, da vsaka država izbere "svoj pristop " pri strategiji, planiranju, razvoju in implementaciji prenove poslovanja in informatizacije njihove "e-uprave«.

V splošnem pa gre za stalno povečevanje in izboljševanje "on-line« upravnih storitev. Te morajo:

- biti cenejše,

- prispevati k razvoju gospodarstva,

- izboljšati »vladanje»,

- izboljšati dostopnost do kvalitetnih (javnih) informacij,

- povečati transparentnost delovanja uprave,

- povečati možnosti za demokratične dialoge.

(Colnar, 2006, str. 218 - 220) 
Marko Colnar

Prenova poslovanja, nastajanje

e-uprave in trenutno stanje v Republiki Slovenji

\subsection{Sklepna misel}

Dejstvo je, da e-uprava vsekakor ni dala tistih rezultatov, ki so se od tega projekta (tudi glede na vložke) pričakovali.

$\checkmark$ zadnjih več kot sedmih letih je bilo zamujenih precej priložnosti. Nenazadnje danes živimo $v$ informacijski družbi, $v$ globalnem svetu, z multimedijo... Od informatizacije sta zelo odvisna tudi gospodarski razvoj in življenjski standard. Seveda se moramo zavedati, da je treba $\vee$ informacijski družbi $k$ razvoju pristopati realno (selektivno, tudi zavedajoč se, da vsi pač nikdar ne bodo komunicirali prek interneta), pa vendar - polovica naše populacije je že uporabnik interneta, vsi upravni organi imajo računalniško opremo, stranke si želijo e-storitev... Vse to bi moralo biti stalno ogledalo za snovalce in razvijalce naše e-uprave.

Nizki odstotki uporabe e-dohodnine, e-podaljšanj prometnih dovoljenj, ki so sicer videti kot privlačne in uporabne e-storitve, nekaj sporočajo. Zelo vprašljivo je npr. večletno vlaganje $v$ razvoj informacijske rešitve e-dohodnine, medtem ko se $v$ letošnjem letu napoveduje odpravo napovedi in odmere dohodnine!

Moram priznati, da pa vendarle ostajam optimist. Zadnji članki v časopisju (poleti 2007) so me prijetno presenetili, ker mi dajejo upanje, da se bo tokrat morda le odprla objektivna razprava o slovenski e-upravi, od nastanka (2001) pa do danes.

Razvoj e-uprave se nikakor ni usmeril tako, kot smo si prvotno zamislili in kot pričakujejo občani, pa tudi zaposleni v upravi. Množica pravnega svetovanja in variacije na nekako tri programske rešitve ter osebne samopromocije posameznikov iz te ekipe, vsekakor niso to, kar naj bi e-uprava bila.

Verjetno sedaj, po vsem tem, po sedmih ali po zadnjih treh letih, ne bo dovolj samo kakšen intervju odgovornega za e-upravo in prenovo slovenske uprave, $v$ katerem bo sedaj ugotovil katere vse bi bile potrebne aktivnosti, ki pa se niso izvajale, kljub pravočasnim korektnim opozorilom, se delno posul $s$ pepelom in želel zgodbo zastaviti na novo, kot da se ni nič zgodilo.

Tudi prepričevanje raznih avtorjev svetovnih primerjav nacionalnih e-uprav, kjer se na lestvicah ne znajdemo na mestu, ki si ga razvijalci želijo, ni pot do ustrezne e-uprave. Istočasno pa vidimo nenavadno visoko uvrstitev naše euprave na lestvici evropske komisije.

Ugotovitev, da nam manjka e-storitev, bolj ali manj drži. Nazivi "elektronske upravne storitve" na portalu E-uprava, za katerimi pa so le informacije in pripet kakšen obrazec, stopnjo uporabe oz. uporabnosti ne bodo povečali. Pa 
še pri tistih nekaj obstoječih e-storitvah je potrebno objektivno analizirati, kakšna je njihova dejanska uporaba.

Torej - nujno je potrebna čimprejšnja realna ocena stanja! Že na prvi pogled pa kaže, da bodo verjetno potrebni drugačni pristopi, kot dosedaj, oziroma korenitejše spremembe na tem področju. Najprej pa se nadejam nadaljevanja objektivne razprave o naši e-upravi, $v$ kateri bi lahko končno sodelovali tudi drugi, ki jim dosedaj ta možnost ni bila dana.

Trenutno stanje naše e-uprave pomeni, da so si bralci (upam, da tudi tega prispevka) oziroma strokovna in širša javnost svojo sliko že ustvarili in jo vsekakor kaže upoštevati. Pretirana suverenost razvijalcev, protestiranje pri ocenjevalcih, vsi dosedanji vložki in dejanski rezultati pa nakazujejo, da si verjetno ne moremo privoščiti "še enega tako uspešnega obdobja slovenske e-uprave», kljub izrednemu rezultatu na lestvici evropske komisije.

Doc. dr. Marko Colnar je diplomiral, magistriral in doktoriral je na Ekonomski fakulteti Univerze v Ljubljani. Leta 2004 je bil na Univerzi v Ljubljani habilitiran za docenta. Sodelovali je pri planiranju in razvoju informacijskih ter organizacijskih sistemov: od priprave metodoloških osnov, pisanja strateških in planskih dokumentov, do vodenja konkretnih informacijskih in drugih projektov. Je tudi avtor več kot 70 strokovnih in znanstvenih prispevkov. Od leta 1984 do 1993 je bil zaposlen na SŽ - Prometni inštitut, od leta 1993 pa v državni upravi (Davčna uprava RS, Center Vlade RS za informatiko, Ministrstvo za šolstvo in šport). 
Marko Colnar

Prenova poslovanja, nastajanje

e-uprave in trenutno stanje v Republiki Slovenji

\section{Literatura in viri}

- $\quad$ Burton M.R., DeSanctis G., Boerge Obel (2006): Organizational Design, A Step-bySpet Approach, Cambridge, Cambridge University Press, , 235 str.

- Center vlade RS za informatiko (2000): EMRIS - Enotna metodologija razvoja informacijskih sistemov, Strateško planiranje, Ljubljana,

- Center Vlade RS za informatiko (2001): MVPDU-IT - metodologija vodenja projektov $\checkmark$ državni upravi - projekti informacijske tehnologije, Ljubljana,

- Colnar M (2006): Ali e-Uprava izpolnjuje pričakovanja?, Portorož, 2006, Dnevi slovenske informatike, Zbornik posvetovanja, str. 126 in CD

- Colnar M.(2005): Kje smo s prenovo procesov v naši upravi?, Portorož, XII Dnevi slovenske uprave, $C D$

- Colnar M. (2006): Kako do prenove slovenske uprave, Ljubljana, , GV Založba, 225 str.

- Grad, Kaučič I., Ribičič C., Kristan I.(1996): Državna ureditev Slovenije, Ljubljana, ČZ Uradni list RS, 470 str.

- Harrington H. J., Esseling K.C.E., van Nimwegen H.(1997): Business Process Improvement, Workbook, New York, McGraw-Hill, , 314 str.

- Heeks R.(2006): Implementing and Manaing eGovernment, London, SAGE Publications Ltd., , 285 str.

- Vidgen R., Avison D., Wood B., Wood-Harper T.,(2004): Developing Web Information Systems, Linacre House, Jordan Hill, Oxford, Elsevier Butterworth-Heinemann, , 274 str.

- Vintar M., Grad J., (2004).: E-Uprava: Izbrane razvojne perspektive. Ljubljana, Upravna misel, , $387 \mathrm{str}$.

- $\quad$ Center Vlade RS za informatiko: e-Poslovanje v javni upravi RS 2001-2004 (SEP2004), Ljubljana, 2001

- Center Vlade RS za informatiko: Akcijski načrt e-Uprave do leta 2004 (AN-2004), verzija 1.3, Ljubljana, 2003

- Certifikatna agencija: http://www.si-ca.si/

- Državni portal e-uprava: http://e-uprava.gov.si/e-uprava/

- i2010 - Evropska informacijska družba za rast in zaposlovanje, SEK(2005) 717, Bruselj, 2005

http://europa.eu.int/information_society/eeurope/i2010/introduction/index_en.htm -

- $\quad$ The User Challenge Benchmarking The Supply Of Online Public Services, 7th Measurement, September 2007, Capgemini for European Commission, Directorate General for Information Society and Media http://ec.europa.eu/information_society/eeurope/i2010/docs/benchmarking/egov_be nchmark_2007.pdf 


\section{Marko Colnar \\ Prenova poslovanja, nastajanje e-uprave in trenutno stanje v Republiki Slovenji}

- Global E-Government 2007, Brown University, Providence, Rhode Island, United States, 2007 http://www.insidepolitics.org/egovtdata.html

- $\quad$ i2010 Akcijski načrt za e-upravo; http://europa.eu.int/information_society/activities/egovernment_research/doc/highli ghts/comm_pdf_com_2006_0173_f_en_acte.pdf

- Ministrstvo za javno upravo: Strategija e-uprave RS za obdobje od leta 2006 do leta 2010 - SEP-2010 »e-uprava za boljšo javno upravo«, Ljubljana, 2006

- Ministrstvo za javno upravo: Akcijski načrt e-Uprave do leta 2010 AN-2007/2010, Ljubljana, 2006

- Ministrstvo za visoko šolstvo, znanost in tehnologijo: Strategija razvoja informacijske družbe v Republiki Sloveniji (Si2010), Ministrstvo za visoko šolstvo, znanost in tehnologijo, Ljubljana, 2007

- Statistični urad Republike Slovenije: Uporaba interneta v podjetjih z 10 ali več zaposlenimi osebami, Slovenija, 1. četrtletje 2007, http://www.stat.si/novica_prikazi.aspx?id=1182

- Statistični urad Republike Slovenije: Uporaba interneta v gospodinjstvih, Slovenija, 1. četrtletje 2007, http://www.stat.si/novica_prikazi.aspx?id=1185

- Zakon o državni upravi (ZDU-1-UPB4), Uradni list RS št. 113 / 2005 


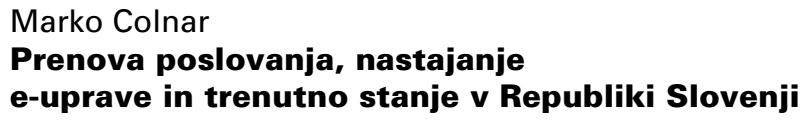

SUMMARY

\section{RENOVATION OF BUSINESS, OCCURRING E-GOVERNMENT AND AT THE MOMENT CONDITION IN THE REPUBLIC OF SLOVENIA}

Modern administration should aim to achieve optimal internal functioning and effective customer operations to the satisfaction of both employees and customers; to a great extent, this can be achieved through e-commerce, provided certain starting points, facts and assumptions are taken into account.

The development of informatisation within the Slovene administration up to now should (like in that of the developed organisations and states we tend to compare ourselves to) have led towards optimizing (manual) functioning of administration, establishing information solutions (first for the so-called 'common functions' in terms of their effective interconnection), and via the Internet towards opening up to customers in a convenient way; all of this should be upgraded with systems for governance and decision-making.

The development of the Slovene e-government up to now has lacked concept, an objective analysis of the needs of customers and employees, and a clear specification of competences of individual ministries, despite the fact that a list of projects for e-services within individual ministries formed an important part of the AN-2004 action plan. As a result, there are several separate web portals in an otherwise common Slovene egovernment: on the one hand there is the State portal 'E-uprava' under the umbrella of the Ministry of Public Administration, on the other hand there are other important portals for electronic commerce of administration bodies which are at least equal in importance as the 'E-uprava' portal (e.g. e-taxes, e-land register, e-cadastre etc). What's more, the Ministry of Public Administration runs and carries out two other projects, one for corporate entities called "e-VEM" and one for citizens "the online extension of a vehicle registration document", which is otherwise a project of the Ministry of the Interior, so the confusion is more than obvious.

Aims, services and data of the e-government, or rather its concept, should be "transposed" into the (re)organisation and better functioning (optimised procedures) of administration bodies. This would give us a framework for a complete reform of operations (instead of just drafting/amending legislation). In addition, both customers and employees in 
administration bodies should be heard as well (what their needs are, where bottlenecks are...). This would provide criteria for determining priorities for the development of individual services within the e-government system.

If we look at the Slovene administration as an organisational system, it is appropriate to approach its reform as systematically as possible; this makes the task significantly easier later on since the analysis itself together with a strict application of appropriate work methods and techniques for displaying results provides models which show a complete picture of the existing state of affairs in Slovene administration, and which can be then used to build the target state of affairs (models) using the same methods and techniques.

The main (but not the only) result for everyone involved - customers and employees (i.e. the users) of e-government - would be a user-friendly web portal which would offer the required and suitable e-services of administration and other bodies interconnected in such a way that customers and employees could solve the majority of the problems, the former from their homes and the latter without the customers. This would rid the employees in administration bodies of most routine and administrative work giving them time for management, decision-making and further operations reform.

To constantly blame the lack of necessary legislative changes for current state of affairs is unproductive and misleading.

Today (re)organisation is an effective tool for the improvement of functioning. In the case at hand, this involves mainly more or less big/small changes in the internal structure of administration bodies in close connection with changes in the structure of administrative and other procedures (but not the change of the procedures themselves). Organisation is a relatively cheap tool and a hidden reserve in the system (there is always room for improvement, which does not require a big investment).

Staff, management and staff management are the foundation of modern organisation, however, members of the staff themselves must change their way of thinking (their attitude towards customers - the buyers of administrative services, their attitude towards the sources for their work $=$ a key to a more effective operations). Special attention should be given to educating managers; the so-called new public management is one of the bases for the professionalisation of modern administration. It involves a constant increase in and a constant improvement of online 
Marko Colnar

Prenova poslovanja, nastajanje

e-uprave in trenutno stanje v Republiki Slovenji

administrative services, which should be cheap and should contribute to economic development, improve governance, increase accessibility to quality (public) information, and augment the transparency of administration operations and possibilities for democratic dialogue.

E-government did not yield the results expected of the project (also from the investment point of view). The low percentage of citizens using e-income tax return and e-vehicle registration document extension, which seem attractive and useful e-services, is sending a negative message. The many years of investment into developing information solutions for eincome tax return has become very questionable since it has been announced that this year income tax return might be abolished. It is essential to make a realistic evaluation of the state of affairs as soon as possible; excessive confidence on the part of developers, protests from evaluators, all of the investments so far and the actual results show that we cannot afford a seemingly successful period of the Slovene e-government despite the exceptional result on the European commission scale.

E-government should be a model for optimal organisation and functioning of administration bodies; it should mainly include those services customers need the most; information solutions of e-government should represent a reduction in administrative burdens for employees in administration bodies; all information solutions of e-government should be simple, while the structure (the selection of services) of the e-government portal should be consistent, clear and transparent. 